\title{
Dijital Medya ve Din Eğitimi: Ayrı Dünyalar?*
}

\author{
BERND TROCHOLEPCZY
}

\section{Özet}

Bu çalışmada din eğitimi ile doğru dijital medya kullanımının birleştirilme sebepleri üzerinde durulmaktadır.

1. Günümüz çocuklarının ihtiyaçlarından bahsedebilmek için, günlük yaşantının gidişatından ve düzeninden ayrılması mümkün olmayan din eğitimi olgusunun ele alınması ve açıklığa kavuşturulması gerekmektedir. Dijital medyanın (bilgisayar tabanlı eğlence, sosyal medya kullanımı, kullanıcı bilgilerinin yönetilmesi vb.) (mir ist unklar, was mit letzterem gemeint ist, aber das könnte auf meine mangelnde Fachkenntnis zurückzuführen sein) çocukların yaşamlarında giderek daha fazla yer alması küresel bir süreç gibi görünmektedir. Çocukların gelecekleri ve meslekleriyle ilgili olarak, yeni medyanın öneminin bireyler için olduğu kadar modern toplumların ilerlemesi açısından da büyük ölçüde artması gerçekçi bir şekilde beklenilmelidir.

2. Din konusuna gelince, kimse dinin medyaya yatkınlığını göz ardı edemez: Din bile hedeflediği kitleye yaklaşmak için teknik araçlardan faydalanmaya ihtiyaç duyar. Din çocukların ve genç yetişkinlerin günlük yaşantılarına/yaşam dünyalarına yakın olduğu için; dinin uygunluğunun güçlendirilmesi, teknik medya gibi dijital ortamlardan faydalanılmasının dinin uygunluğunun ötesinde bir şey olmadığının ve modern toplumların tüm üyelerinin gerçek dünyalarına uzandığının gösterilmesi anlamına gelmektedir. Nihai gerçeklik zeminiyle olan temel ilişki hiçbir şeyi sınırları dışında bırakmamaktadır.

* Bu çalışma, 1. Türkiye Çocuk ve Medya Kongresi'nde bildiri olarak sunulmuş ve Kasım 2013 tarihinde I. Türkiye Çocuk ve Medya Kongresi Bildiriler Kitabı (cilt 2) içerisinde Ayşe Aksakal çevirisi ile yayımlanmış metindir.

- GÖRÜS-

BERND TROCHOLEPCZY

doi: https://doi.org/10.47646/CMD.2021.263 
3. Görselleştirme kapasitesi ve mantıksal yapının çok basit bir şekilde sunulabilmesi nedeniyle, dijital medya din eğitimi açısından son derece faydalı araçlar sunar. Din, katılaşmış ve nesnel bir inanma biçiminden ibaret değildir. Bunun yanı sıra, dini bakış açısıyla da yorumlanacak durumlarla ilgili yeterli bilgi edinmek için çok çaba gösterilmelidir. Farklı durumlarda bilgiyi başarılı bir şekilde kullanabilme kapasitesi, yeterliliğin ne olduğunun anlaşılmasını sağlayan anahtardır. "Yeterlilik", düzenleyici bir fikir olan, kurumsal ve resmi ortamlarda (okul, üniversite vb.) öğrenme fikrine giderek daha fazla dönüşmüş gibi görünmektedir. Medyada yeterlilik ve dini bilgi yeterliliği birlikte artabilir.

4. Frankfurt Goethe Üniversitesi'nde 2005 yılından bu yana bilgisayar destekli din öğrenimine dair deneyim edinme şansımız oldu. Alman Piskopos Konferansı (DBK) tarafından ısmarlanan bir internet platformunu projelendirdik, gerçekleştirdik, uyguladık ve son olarak ancak -aynı derecedeönemli değerlendirdik. Platform tüm okul türlerinde ilkokul ve ortaokul seviyesinde din eğitiminden sorumlu Almanca konuşan Katolik Öğretmenlere hitap etmektedir. Değerlendirme yoluyla, bilgisayar destekli din öğreniminin kullanışlılığını ve eğitim kurumlarındaki din eğitimi için faydalarını kanıtlayabiliriz.

\section{Abstract}

The paper is concerned with relevant reasons to combine religious learning with the competent use of digital media.

1. To start with the needs of today's children one has to reflect and clarify the phenomenon of religious learning, which cannot be separated from the conduct and practice of daily life. It seems to be a global process that digital media (i.e. computer based entertainment, the use of social media, management of user-relevant information etc. (mir ist unklar, was mit letzterem gemeint ist, aber das könnte auf meine mangelnde Fachkenntnis zurückzuführen sein) has become more and more part of children's every day lives. As to the future and later professions of children one has to realistically expect an immensely increased importance of new media for individuals as well as for the progress of modern societies.

2. As to religion, no one can ignore the mediacy of religion: even religion has to use technical instruments to come close to those it addresses. Because of religion's closeness to the every day lives/the lifeworld of children and young adults, strengthening the relevance of religion means to show that and extends into the real world of all members of modern societies. The fundamental relation to the ultimate ground of reality leaves nothing outside of its range. 
3. Due to the capacity of visualization and the possibility to represent logical structures in a very elementary way, digital media are very useful instruments for for teaching religion) Religion is not only the concrete and practical way of believing. In addition it needs every effort in order to acquire a competent knowledge in relation to situations which are also to be interpreted in a religious way. The capacity of using knowledge successfully in different situations is the key to understanding the meaning of competence. And "competence" seems to have become more and more the regulative idea of learning in institutional and formal settings, as for example in schools and universities. Competence in media and competence in religious knowledge may grow together.

4. At the Goethe University in Frankfurt we had the chance to gather experiences with computer based religious learning since 2005. We conceptualized, realized, implemented and last but not least evaluated an internet platform commissioned by the German Bishops-Conference (DBK). The platform addresses all German-speaking Catholic teachers responsible for religious education in primary and secondary schools of all school-types. By evaluation we can prove the usefulness of computer based religious learning and its benefits for religious education in educational institutions.

Öğretmenler ve çocuklar tarafından dijital medyanın yetkin şekilde kullanımı ile din eğitimi ve öğrenimini birleştirmek için yadsınamaz nedenler vardır. İlginç şekilde sadece çocuklar için değil ayrıca dinin anlaşılması için de kazan-kazan durumu vardır. Modern toplumlarda çocukların etkileşime girmelerine yardımcı olmak, başa çıkmaları gereken tüm zorlukları karşılamada gençlere yardımcı olmak anlamına gelmektedir. Zamanımızda dini anlamak, gerçeğe dinsel ve teknik yaklaşım arasındaki inkar edilemez farkı kabul etmektir.

Din her zaman her ırktan ve her kültürden insanı kontrollerinin dışında kalan ve türümüzün ilk günlerinden beri tam olarak hükmedemedikleri şey ile yüz yüze getirmiştir. Bunun tam aksine de, günümüzün modern dijital teknolojisi insanın neredeyse her sorunu çözebilme becerisini ve etkinliğini kanıtlar gibi görünmektedir.

Her iki paradigma da modern dünyamızda her an her yerde var olduğu için, uygulanan farklı görüş açıları nedeniyle ilk bakışta birbirlerinden çok farklı gibi görünmelerine karşın, çocukların, her iki perspektifi de öğrenmek için yardıma ihtiyacı vardır. Modern dünyamızda bir dünyada yaşamak ve insanoğlunun yapabileceklerinin limitinin ne olduğunu ve nerede durduğunu anlamak din eğitiminin öncelikli hedefidir. Dijital teknolojinin 
kesinlikle "nötr" olmaması aksine modern teknik dünyayı tüm bilimsel, kültürel, politik boyutları içinde yönetme eğilimiyle insanın etkinliğini çok büyük oranda arttırması nedeniyle eğitim bağlamı içinde bu teknolojiyi kullanmanın neredeyse hiç alternatifi yoktur.

Dijital devrim yaşamlarımızı ve yaşam koşullarımızı radikal bir şekilde değiştirmektedir ve şu anda biz kendimizi bu değişimin sadece başında buluyoruz. Yine de bu devrim bizim zaten iyi bildiğimiz bir şeyi kanıtlamaktadır. Bu nedenle ima ettiğini soruya dökmüyoruz: Modern teknolojinin yaygın doğasının kendisini. Bu devrim belki de tarihte ilk defa zapt edemeyeceğimiz ya da durduramayacağımız küresel bir devrimdir. $\mathrm{Bu}$ nedenle uygun tüm eğitim çalışmalarının amacı yapabileceklerinin ve olasılıklarının ötesinde ne olduğunun anlaşılması ve anlatılması olmalıdır.

Eğitim çerçevesinde dikkate alınması ve saygı duyulması gereken önemli bir durum vardır: Dijital medyanın yetkin şekilde kullanımını genişletmek üzere başarılı bir strateji oluşturmak için, ilk önce öğretmenleri ve eğitmenleri ele almak gerekir ve sonrasında ikinci bir adımda ve bu ilk çabaların bir sonucu olarak 21. yüzyıl teknolojilerinin sunduğu fursatlar ve riskler konusunda farkındalık geliştirmeleri için çocuklar ve gençlere tavsiyelerde bulunulmalıdir.

Modern iletişim ve bilgi teknolojisinin yetkin şekilde kullanımı kullanıcıyı çeşitli bağlamlarda teknolojinin en iyi ve en sorumlu uygulamasını bulmasını sağlamak ve kullanıcıların bireysel gereksinimlerine uygun şekilde dijital medyadan faydalanmak anlamına gelmektedir. BT teknolojisinin verimli kullanım olasılığı ise yine de sınırlıdır çünkü sınırları dahilinde gerçekten her şey neyse odur.

Dijital medya üzerine bu düşünceler hiçbir suretle dijital medyanın reddi olarak anlaşılmamalıdır; bu yalnızca sınırlarının kabul edilmesine yol açar. Bu önemli ve yaygın sorunu anlamak ve onunla yüzleşmek çok önemlidir; bununla başa çıkmada başarılı olmak için öğretmenlerin ve çocukların kurumsal yardıma ve desteğe ihtiyacı vardır.

\section{I.}

Bugünün çocuklarının gereksinimlerinden başlarsak, onların deneyim dünyasının koşullarını yansıtmak ve netleştirmek gereklidir. Çocukların gündelik hayatını anlamak çocukların kendisini anlamaktır. Çocukluk, bireylerin kültürel, tarihsel, toplumsal ve son olarak günümüzün teknolojik etkilerinden ve değişikliklerden ayrı tutulabilecek ebedi bir fikir kesinlikle değildir. Çocukların doğasını anlamak için, ilk önce çocukların nerede yaşadıklarını bilmek ve nasıl zaman geçirdiklerini anlamak gerekir. 
Zaman ve yer kavramlarının felsefi tartışmalardaki yeri ne olursa olsun kimse dijital devrimin öncüsü olan teknolojinin gündelik yaşamımıza sürekli olarak müdahale ettiğini inkar etmeyecektir. Bir şekilde, 21. yüzyıl dijital medyası çocukların ve gençlerin şu anda bulundukları somut yeri marjinalleştirme eğilimindedir.

Uygun dijital araçlara erişimlerinin olması şartı ile, kişiler konumlarından tamamen bağımsız olarak istedikleri anda birbirleriyle bağlantı kurabilirler. Birbirleriyle bağlantılıdırlar çünkü bilgiyi nakleden ve ileten son derece fazla çeşitte dijital araca erişimleri vardır ve oldukça yeni ve şaşırtıcı bir unsur olarak aynı şekilde yararlı eğitim araçları ile de potansiyel olarak birbirleriyle bağlanabilirler. Bulunulan yerin marjinalleşmesinin yanında bir başka marjinalleşme daha vardır: Zaman faktörünün devreden çıkıyor gibi görünmesi. Doğru dijital araç yakınlardaysa kişi istediği her zaman telefon görüşmesi yapabilir, iletişim kurabilir ve mesajlaşabilir.

Şüphesiz ki, dijital medya (yani bilgisayar destekli eğlence, sosyal medyanın kullanımı, kullanıcıya ilişkin bilgilerin yönetimi vb.) gittikçe artan şekilde çocukların günlük hayatlarının son derece önemli bir parçası haline gelen küresel bir süreç gibi görünmektedir.

Gençler ekran önünde gittikçe daha fazla zaman korkunç derece artan dakikalar ve saatler geçirmektedir. Belki bir gün arkadaşlarıyla yüz yüze gerçek zamanlı iletişim kurmak için harcadıkları süreden daha fazlasını dijital arayüzler önünde iletişim kurmak için harcayacaklar.

Bir yandan çocukların ve gençlerin ihtiyaçlarını, diğer yandan da onların doğal gereksinimlerini mükemmel bir şekilde karşılayan dijital medyanın baştan çıkarıcı gücü hakkında birşeyler öğrenebileceğimiz üç örnek vermek istiyorum.

a. Frankfurt Üniversitesi kafeteryasını son ziyaretlerimde gittikçe daha fazla öğrenci arkadaşlarıyla konuşmak yerine kendi başlarına oturup, akıllı telefonlarını kullanıyor, kısa mesaj, tweet ya da mail atıyor gibi göründü bana. Her ne kadar aynı masada yan yana otursalar da, birbirleriyle konuşmuyor, onun yerine kendilerini tümüyle dijital araçlarında mesaj yazmaya kaptırmış görünüyorlardı. İtiraf etmeliyim ki onlara ayak uydurabilecek ya da onları taklit edecek kadar yetenekli değilim.

b. Metroda gelirken artan sayıda ilkokul birinci sınıf öğrencisinin bile birbirleriyle konuşmaktan çok elektronik araçlarıyla (müzik dinlemek, oyun oynamak vb) daha ilgili olduğunu fark etmeden duramadım. Ancak için kolay hedef haline getiriyor, onları suçlayamam. Kendimi modern 
toplumlarımızda neyin yanlış gittiğini ve benim eğitim ihtiyaçlarımın ne olduğunu ve gerçekten misyonumun ne olduğunu düşünme konusundaki çabalarımı artırmak zorunda hissediyorum.

Şüphesiz ki, dijital teknikler yetişkinlerin olduğu kadar çocukların ve gençlerin de hayatlarında belirgin bir unsurdur. Tüm istatistik kayıtları dijital araç alanındaki satışlarda hızlanan büyük bir büyüme olduğunu kanıtlamaktadır ve istatistikler ayıca sosyal ağ hizmetlerinin artan kullanımını da belgelemektedir.

c. Her yıl, Goethe Üniversitesi yaşları sekiz ile on iki arasında değişen çocukları Çocuk Üniversitesine kaydolmaları için davet eder. Orada çok sayıda ders ve kurs verme firsatım oldu. 2011'deki konum şu başlığı taşıyordu: "İnternet ile Arkadaş Edinmek? Blog Tutma ve Mobbing Hakkında". Sekiz ile on yaşları arasındaki çocuklardan kaçının Facebook'a üye olduklarını açık bir şekilde onaylayacaklarını bilmek istedim. On üç yaş sınırı olduğunu bildiğim için sorduğum 1000 çocuğun yarısından fazlasının Facebook'u kullanarak arkadaş bulabildiklerini öğrendiğimde gerçekten çok şaşırdım. "Like (beğenmek)" düğmesine basmaktan gerçekten keyif aldıklarını, arkadaşlarıyla bilgi paylaşmaktan hoşlandıklarını ve ayrıca kendilerini çok büyük ve hızla büyüyen bir toplumun üyesi olarak gördüklerini itiraf ettiler.

Çocuklara sordum: "Sosyal Ağ sitelerine katılma nedenleriniz nelerdir?". Çocukların motivasyonu konusunu araştıran hiç kimse cevaplara şaşırmayacaktır; neredeyse tüm cevaplar birbirine benzemektedir: "Arkadaşlarımız dijital ağlar kullanıyor." / "Onlarla bağlantılı olmak istiyoruz." / "Hangi bilgileri paylaştıklarını ve ilettiklerini bilmek istiyoruz." / "Bir topluluğun üyesi olmamak yalnız kalmak anlamına geliyor."1

Çocuk için bu en korkutucu kabus gibi görünüyor: Geride bırakılmak, yalnız olmak, bu (meçhul) yüzsüz toplumun dışında kalmak ve ayrı olmak.

Anneleri olmadığında bebeklerin kaybolacaklarını anlamak için kimsenin bilimsel çalışmalara ihtiyacı olmaz. İnsan prematüreliği olgusu nedeniyle anne-babaları olmadan bebekler tamamen savunmasızdır; iyi beslenmeyen bebekler ölmeye mahkumdur. Ve bu bağlamda yemek için ağlamak yaşamak için ağlamaktır. Felsefi ve antropolojik bir görüş açısından biliyoruz ki insan olmak ilk önce hitap edilmek ve sonrasında bunun karşılığında cevap vermek anlamına gelir. İnsanoğlu konuşkan bir varlıktır. Bu nedenle kimse 
yalıtılmış bir şekilde yaşayamaz. İnsan ada değildir ve yalnız, insanlardan uzakta yaşayamaz; bu temel içgörüyü netleştirmek için tek bir cümle söyleyebiliriz: Tek bir insan insanoğlu değildir. Sosyal dışlanma, kaygı, ölüm korkusu ve depresyon arasında temel bir ilişki vardır.

Ancak bu asli ilişkileri bildiğimden dolayı çocukları sosyal ağların büyüsüne kapıldıkları, kısa mesajlaştıkları ve Whatsapp kullandıkları için suçlayamam.

Çocukların bir başka temel ihtiyacı da dünyayı keşfetmek ve bunu oyun oynayarak yapmaktır. Oyunlar ve çocuklar her zaman bir bütün oluşturur. Oyunlar bebekler ve küçük çocuklar için yiyecek kadar zorunlu gözükmektedir. Burada yaşamsal gereksinimler söz konusudur.

Oyun oynarken çocuklar, anneleri yakınlarda olmasa bile kendilerini yalnız hissetmezler; birçok oyun düzeni arkadaş gerektirir; işbirliği ve etkileşim yaşamın daha ileri dönemlerinde sosyal ilişkiler kurabilme becerisini şekillendirir. Ancak kimse işbirliği yapmasa bile oyunun kendisi bir tür arkadaş/partnerdir ve bir şekilde yüz yüzedir.

Sosyal ilişkilere açık olmak, anlamın bütünsel bir şekilde yapılandırılmış geçmişi olarak dünyaya açılmak kadar önemlidir. [bkz. örn. Martin Heidegger, "Varlık ve Zaman"; söylemlerinden birinde Heidegger yeni doğan bir bebeğin ilk yüz yüze kaldığı şeyin anlam olduğuna işaret eder.] Anlam ile karşılaşmak küçük çocukların temel gereksinimidir. Şüphesiz ki oyun oynamak insan için anlamın özü olarak dünyayı açar. Çocuk oyun oynarken her şeyin arkasında bulunmayı ya da deneyim yoluyla üretilmeyi bekleyen bir anlam olduğunu keşfeder.

Arkadaşlı ya da arkadaşsız oyun oynamak kuralların düzenlemesine, soyut şeylere ve oluşumlara odaklanılması anlamına da gelmektedir. Oyun sırasında kişinin konsantrasyonu bozulmasın diye rahatsız edilmemek hep zordur, bu da bir şeye odaklanmayı ya da yakınlığı halinde öz-kontrol gücünü artırmayı daha da gerekli kılar. Bu kuvvetlendirici güçlerle başa çıkmak insan praksisini (insan olmayı) öğrenmektir. Bu da sonuçta insan olmak anlamına gelir. Çocuğun öğrenmesini "kendiliğinden yuvarlanan bir çember, ilk hareket" olarak tanımlayan Nietzsche'ydi [“Masumiyettir çocuk ve unutkanlık, yeni bir başlangıç, bir oyun, kendiliğinden yuvarlanan bir çember, ilk hareket ve mukaddes bir evettir”, F. Nietzsche, Böyle buyurdu Zerdüşt, Zerdüşt'ün Sözleri]. ${ }^{2}$ 
Bir çerçeve sunmak açısından benim için en önemli olanları özetlemek istiyorum: Oyunlar aracılı̆̆ıyla, örneğin oynayarak çocuk insanları (sosyal ilişkiler), dünyasını ("anlam vardır”) ve eylemin kaynağı ve kökeni olarak kendini ("kendiliğinden yuvarlanan çember, "ilk hareket" olmayı) keşfeder.

Hiç kimse çocukların eğlence dünyası içinde dijital medyanın artan ilgisini görmezden gelemez. Siber alanda dijital destekli iletişim, rol oynama ve gerçek zamanlı hareket etmeye yardımcı olan dijital medya ile çocukları hedef alan dijital endüstrinin çok belirgin başarısının nedeni nedir?

Bredow-Enstitüsü Bremen, Almanya, [Schmidt 2009] çocuklar ve gençlerin üç web tabanlı fonksiyon alanında sosyal yönetim, kimlik yönetimi ve bilgi yönetimi gittikçe daha fazla zaman geçirdiğini belirten ampirik bir çalışma yayınladı. ${ }^{3}$ ["kimlik yönetimi" teknik teriminin tanımının daha geniş anlamıyla karışmaması için, "kimlik yönetimi” yerine öz yönetim terimini kullanmayı teklif ediyorum.]

Burada en çarpıcı olan besbelli ki temel gereksinimlerin bir yanda yönetime diğer yanda web'e, yani dijital araçlara ve yararlı yazılımlara devredilmesidir. Anlamlı bir dünya oluşturarak ve kişinin kişiliğini yaratıcı bir özgürlük içinde biçimlendirerek sosyal ilişkilerle ilgili "ihtiyacı" tanımlayan şey, kendi gücü nedeniyle yaşamın temel gereksinimlerini yönetme becerisine sahip olmayan insanoğlu şeklinde Kendini ortaya koyar.

Bebek beslenmek ve büyümek için ebeveynlerine bağlıdır; çocuk dünyanın kendisine anlamını açmasına bağlıdır ve daha geniş anlamda, gençler de Nietzsche'nin "kendi kendine yuvarlanan tekerlek" fikri bağlamında kendi güçlerini kullanmak için kendi özgün doğalarının sınırlarına bağlıdır.

İletişim kurmaya ve muhatap alınmaya yönelik temel gerekliliği artık bildiğimiz gibi, dijital medyanın ayrıca oyun oynamaya ilişkin temel gereksinime de yanıt verdiğini biliyoruz. Çocukların oyunlarda harekete geçme becerilerini deneyimlemeden kişilik ve zeka geliştirmeleri olanaksızdır.

Ancak hepimiz "ego shooters (birinci şahıs nişancı)" gibi oyunların uyarımları abartma eğiliminde olduğunu biliyoruz, dijital oyun oynamanın yerleşik bileşeni olarak belirgin anlam alanı, oyun oynayan kişinin tüm dikkatini oyuna vererek bir sonraki düzeye geçme konusuna kilitlenmesine neden olmaktadir.

3 Schmidt, J.-H. (Hrsg.) (2009), Heranwachsen mit dem Social Web. Zur Rolle von Web 2.0Angeboten im Alltag von Jugendlichen und jungen Erwachsenen, herausgegeben vom HansBredow-Institut für Medienforschung, Hamburg/ Salzburg. 
Hepsinden öte, birçok dijital oyun çocukların oynamaya devam etmelerini sağlamaya çalışıyor çünkü bunu sağlayacak gelişmiş ödül sistemleri var. Birçok dijital oyun üreticisi bilgisayar ve web tabanlı oyunlara para ve zaman harcamaları için gençleri baştan çıkartıyor. Çoğunlukla psikologlar danışman olarak katkıda bulunuyorlar çünkü oyun üreticileri iyi hesaplanmış etkitepki modelleriyle çocukların dikkatini nasıl çekeceklerini bilmektedir. Bana çocuk zihinlerini gerçekten önemli olan şeylerden uzaklaştıran çok oyun varmış gibi geliyor.

Birçok özenli sorgulama "çok sayıda ancak zayıf bağlar" diye tanımlanan sosyal ilişki olgusundan rahatsızlık duymaktadır. Sosyal ağ hizmetleri bağlamında, nicelik niteliğin yerini alma eğilimi gösteriyor gibi: Çocuklar sahip oldukları arkadaş sayısını karşılaştırmaktadır. Birçok sosyal ağ kullanıcılarının arkadaş sayılarını düzenli bir şekilde artırmaları konusunda teşvik etmek için kullanıcıların arkadaş sayısını, açıkça göstermektedir. Gene, yönetim kişilerin temel kişisel yakınlık ve yakın olma "ihtiyacını" bulanıklaştırma eğilimindedir.

Dijital medyanın bir başka taahhüdü de özyönetimde başarılı olmaktır. Ancak yaratıcı özgürlük bulma ve kimliği şekillendirme temel ihtiyacı, gerçekleştirilmesine yönelik dijital girişimlerle bir şekilde değiştirilmektedir. Örneğin “öz yönetim” terimi bağlamında dijital tabanlı bir kimlik yaratmak bir "profil” geliştirmektir. Sosyal ağlar konseptine ilişkin olarak, kişi kategorik zorunluluğa koşulsuz olarak uymak zorundadır: "Sadece iyi ve beğenilebilir olduğunu gösterme kuralına uygun şekilde katılım yapmak."4

Bu kurala uymak için birçok neden vardır çünkü siber uzaya girilen hiçbir yazı kaybolmayacaktır, belleği neredeyse hatası/eksiksizdir ve "unutkanlık suları" 5 yoktur. Dijital medya kullanıcısı günün birinde "dijital geçmişinde" yaptığı hatalarla karşılaşacağını her zaman öngörmelidir. Bu gerçekçi tehdit "yeni bir başlangıç" bağlamında kişilerin "kendiliğinden yuvarlanan çember" olmalarına engel olabilir.

Bilgi yönetimi dünyayı keşfetmeye yönelik temel insan ihtiyacına karşılıkmış gibi görünmektedir. Dijital araçların yardımıyla çocuklar ve gençler herhangi bir bağlamda ya da durumda gereken neredeyse her türlü bilgiyi bulacaktır. Her zaman her yerde bulunan bilginin cazibesi son derece güçlüdür; internet kullanıcısı her şeyi her zaman ve her yerde bilerek neredeyse "her şeyi bilen" olarak gözükmektedir.

Çocuk ve Medeniyet 2021/2
4 Immanuel Kant, Ahlak Metafiziğinin Temellendirilmesi

5 Day-Lewis, Cecil (çev.) (1952). Vergilius, Aeneis. s. 705. 
Kimse dijital medya fazlalığını inkar edemez. Bugün İskenderiye Kütüphanesi'nin kurucu atalarının var olan tüm kitaplara sahip olma hayali bizim için gerçek haline gelmiştir. Aslında dijital araçlara sahip her çocuk bilginin korkunç büyük ve sonsuz evrenine girebilecektir. Ancak birçok web sitesinin kullanıcılarının profiline uygun bilgiyi teklif eden "filtre baloncukları” olduğunu biliyoruz. İlk başta önemli gibi görünen şey sadece algoritmalarla hesaplanmaktadır.

Böylelikle anlam bilgiye dönüşür ancak bilgi anlamdan kuvvetli şekilde farklılaşır. Dünyalarını geliştiren araçları fiziksel olarak denemek insanın bebeklikteki temel ihtiyacıdır. [Bu arada dualara genelde fiziksel jestlerin eşlik etmesi önemlidir. Duanın bilgiyle bir alakası yoktur ancak sadece anlam bağlamında anlaşılması gerekir.]

Toparlamak adına altını çiziyorum: Dijital iletişimin, oyun oynamanın, bilgi edinmenin kuralları, çocukların temel gereksinimlerini karşılıyormuş gibi görünmektedir. Dijital medya çocukların temel gereksinimlerini karşıladığı ölçüde başarılı ve çekicidir.

Ancak dijital teknoloji, iyileştirme anlamında başarılı olduğunda aynı anda güçlï değişiklikler ortaya çıkar: Oluşması ve verilmesi gereken şey bir tekniğe, "manipülasyon” olarak anlaşılan ve yüksek etkinlikle birleşmiş öngörülen yönetime dönüşür. Ancak tüm modern toplumların asli ve gelecek odaklı bir parçası olduğu için dijital medya kullanımına gerçekçi bir alternatif olmadığından dolayı dijital medya bugün çocukların benzeşen yaşamlarının silinmez bir parçasıdır. Kimse dijital medya kullanımı ve sınırların öğrenilmesinden dolayı bu şekilde suçlanmamalıdır.

Dijital medyanın sınırları insanın temel ihtiyaçlarına cevap vermediği gerçeğinde görülebilir. İște bu bağlam, öğretmenler üzerine eğitime yönelik bir sorumluluk yüklemektedir. Çocuklara ve gençlere dijital medya kullanımlarında eşlik etmek için öğretmenleri yetkinlik ve dijital okuryazarlık kazanmaları konusunda eğitmek önemli bir iştir.

\section{II.}

Din olgusu ne insan gereksinimlerine indirgenebilir ne de bugünün çocuklarının gereksinimlerinden ayrı tutulabilir, bu konuda inancım tam. İnsanların günlük yaşamlarında yaptıklarından ve uyguladıklarından ayrı tutulamayan din eğitimi olgusuna ilişkin üzerinde kişinin düşünmesi ve anlaması gerekir.

Din çocuklar söz konusu olduğunda ve teolojik bir görüş açısından kesin bir içerik barındırmaz ve her şeyden önce inanılması gereken bir seri dogmayla 
sınırlı değildir. Din eğitimin en önemli öğesi olarak bir günlük hayat olgusudur. Başlangıçta insana yalnızca kuramsal değil çok somut bir şekilde hitap edilir. İnsan din tarafından çağrılır, hitap edilir ve gerekli teslimiyeti göstermesi beklenir.

Bu teslimiyet her zaman temel bir yaşam praksisini (uygulamasını) yansıtır. [Düşüunmenin bile bir "uygulama" olması önemlidir.] Din eğitimi bağlamında, bu da çocukların ve gençlerin gündelik yaşamlarının pedagojik ve didaktik alanında kaçınılmaz bir çekişme anlamına gelir.

Kimse dinin aracıya ihtiyacı olduğunu göz ardı edemez. Din hitap ettiklerine yakınlaşmak için medyayı kullanır ve bir şekilde dinin gerçeklemesi medya kullanımı ile ilişkilidir. Ancak din olgusunun antropolojik bir görüş açısından başlayan uygun teolojik bir tanımlaması yoktur. Din, basitçe insanoğlunun ihtiyaçlarına indirgenemez. Aksi takdirde Tanrı'nın insan isteklerine cevap verme aracına indirgenebileceğine dair bir şüphe doğacaktır. Böylelikle din somut durumlarında kişiye hitap eden Tanrı etkinliğinin önemini vurgular.

Tanımlanabilen tüm temel ihtiyaçlar, $\mathrm{O}$ dinin anlam dünyasını oluşturan; görülebilir ipuçlarıdır; din olgusu sosyal toplumlarla yakından bağlantılıdır; ve dinin temel taahhüdü, teslimiyeti oranında kişiyi bağlarından kurtarmaktır çünkü teolojik açıdan bakıldığında özgürlük ve teslimiyet nispeten Tanrı bıkıp usanmadan insanoğlunun bütünlüğü ile ilgilenirken gelişir.

Tüm bu dini taahhütlerin doğruluğu her gün kanıtlanmalıdır. Ve kişinin günlük hayatının tekdüzeliğinde bile bunları kanıtlamanın başka yolu yoktur. Bir şekilde din ve dijital medya, her ikisi de çocukların temel gereksinimlerini karşılamanın tek yolu olmadıkları için birbiriyle rekabet ederler. Ve her ikisine de taahhütler eşlik eder.

\section{III}

Rekabet güçlü bir ilişkidir. "Gereksinim" olgusu teknolojik, dijital terimler ya da "iyileştirme"nin diğer modern terimleri ile karşılanamaz. Ancak bugünün dünyasında yaşamak şirketleri, okulları, üniversiteleri iyileştirmek anlamına gelir ve bazıları insanların bile iyileştirilmesi gerektiğini öne sürer.

İşte tam da bu nedenle din eğitimini dijital medya kullanımdan ayırmak yerine bu ikisini birleştirmek gerekir. Anne babalarla öğretmenler, çocuklar ve gençler dijital medyayı kullanırken onlara eşlik etmek ve dijital medyayı dikkatlice kullanmayı öğretmek zorundadır. Dikkatli olmak bir şekilde 
öz-düşünümsel (self reflexive) olmaktan farklıdır. İnsanların günlük hayatlarında modern dijital medyanın etkisiyle ilgilenen olgusal bir yaklaşım bulmak kaçınılmazdır ve aynı zamanda yeterince zordur. Fenomolojik yaklaşım "kendisinin, kendisi gösterir gibi, kendisini kendisinden gösterdiği şekilde görülmesine izin vermektir."6

Bu zorlu sorun ne kadar güç olsa da acilen kurumsal bir destek gerektirir. Dijital yetkinliği ve okuryazarlığı iyileştirmek için üniversitelerin, devletin ve din kurumlarının bu fenomene dikkat etmesi zorunludur.

Katıldı̆̆ım girişimlere yönelik çok somut bazı örnekler vermek istiyorum.

1. Frankfurt Goethe Üniversitesi'nde 2005 yılından bu yana bilgisayar destekli din öğrenimine dair deneyim edinme şansımız oldu. Alman Piskopos Konferansı (DBK) tarafından ısmarlanan bir internet platformunu projelendirdik, gerçekleştirdik, uyguladık ve son olarak değerlendirdik. Platform tüm okul türlerinde ilkokul ve ortaokul seviyesinde din eğitiminden sorumlu Almanca konuşan Katolik Öğretmenlere hitap etmektedir. Değerlendirmemizin yardımıyla bilgisayar destekli din öğreniminin kullanışlılığını ve eğitim kurumlarındaki din eğitimi için faydalarını kanıtlayabiliriz.

2. Goethe Üniversitesi'nde tüm fakültelerin (16), 40.000 fazla öğrenci için dijital destekli öğrenmeyi iyileştirmeye katkıda bulunduğu "studiumdigitale" denilen bir ağ yürütüyoruz. Her yıl, öğretim ve öğrenimde dijital medyanın kullanımının iyileştirilmesi konusuyla ilgilenen öğrencilerin katıldığı bir yarışma düzenliyoruz. Başarılı projeler tanıtılmakta ve finansal sponsorluk ile desteklenmektedir. [15.000€ böyle bir proje için sunulan en yüksek miktardır.]

3. Goethe Üniversitesi'nin 14 fakültesinin hepsinden oluşan ve (ilkokul ve ortaokulda öğretmenlik yapmak isteyen öğretmen stajyerlerini hedef alan) öğretmen eğitimine katkıda bulunan bir ağ olan "Eğitim Araştırmaları ve Öğretmen Eğitimi Akademisi” tüm stajyer öğretmenleri (Goethe Üniversitesi'nde yaklaşık 6.500 kişi), yukarıda bahsedildiği şekilde dijital medyayı dikkatli ve sorumlu bir şekilde kullanma konusunda çocuklara ve gençlere eşlik edebileceklerini gösteren bir dijital medya sertifikası almaya davet etmektedir.

Farklı fakültelerden meslektaşlarımla beraber medya sertifikası fikrinin oluşturulması ve geliştirilmesine katkıda bulunduğum için gurur

6 Martin Heidegger, Varlık ve Zaman. Çeviren: John Macquarrie ve Edward Robinson, Oxford 1962, s. 58. 
duyuyorum. Bu sertifika programının yönetiminden sorumlu olarak sürekli biçimlendirici değerlendirmeler yaparak bu akademik kursu iyileştirmek üzere elimizden gelenin en iyisi yaptığımız konusunda sizi temin ederim.

Hesse eyaleti yönetimi ile işbirliği içinde sadece üniversitedeki öğrencilere değil ayrıca öğrenci, öğretmenler ve öğretmenlere hitap eden eyalet çapında bir dijital medya sertifikası geliştirmek için çok çalışıyoruz. Sadece Hesse yönetimi değil ayrıca Hesse'de yer alan tüm üniversiteler (Darmstadt, Gießen, Marburg, Kassel ve Frankfurt) bu projeye dahil olmuştur. Bunlara ek olarak, farklı bölgelerin okul yönetimindeki yöneticiler de projede yer almaktadır.

4. Din eğitimi ve öğretiminin Alman okul müfredatının ayrılmaz bir parçası olmasından dolayı (bkz. Alman anayasası GG 7. maddesi, Abs.3) uzmanlık alanım "din ve medya eğitimidir".

Kurslarımda ve derslerimde dijital medya kullanmaktan ve iyi niteliklerini ve sorunlarını, avantajlarını ve dezavantajlarını tartışmaktan asla kaçınmadım; bu şekilde öğrenciler örneğin etkileşimli beyaz tahta ve 21. yüzyılın diğer araçlarını yeterli şekilde kullanmayı öğrenmektedir. Öğrenciler Etherpad'i kullanarak geri bildirim vermede ya da tartışma gruplarında toplanılan bilgileri özetlemede başarılı olmaktadır; birçok öğrenci kendi araçlarını (akıllı telefonlar, tabletler, dizüstü bilgisayarlar) getirirken, diğerleri onlara Goethe Üniversitesi'nin tahsis ettiği araçlardan faydalanmaktadır. Aslına bakarsanız çocuklara din ile ilgili anlamlı bilgiyi nasıl edinebileceklerini öğretmek üzere WebQuest yöntemlerini uygulamaya alıştılar. Farklı dinlerin perspektiflerini anlamak için dijital bilgiye başvuruyoruz (Second Life, Facebook) ve ayrıca her şeyden önce özgün girdilerini istediğimiz farklı inançtan uzmanlara ve inananlara da hitap ediyoruz; sadece akademik öğretimin genelde çok beğendiği kavramsal açıklamalar sunmalarını istiyoruz.

Kesinlikle başka örnekler de verebilirim ancak benim niyetim günlük hayatlarında dijital olarak başarılı olmaları için çocuklara yardımcı olmak üzere öğretmenlerin dijital yetkinliğini artırmayı amaçlayarak adım adım ilerleme firsatını göstermektir.

İki yönden sınırlamayı yaşamaktan kaçınmanın yolu yok.

Çocuk ve Medeniyet 2021/2
Bir tanesi içeride ne olduğunu, diğeri ise o sınırların ötesinde ne olduğunu gözler önüne sermektedir. İnsanoğlu ölümlü bir varlıktır; çocukların savunmasızlığı bu gerçeği gösterir. 
Çocuklar ebeveynlerinin ve öğretmenlerinin ilgisine ihtiyaç duyarlar; öğretmenlerin kendisi ise bu makalede altını çizdiğim görevleri yerine getirebilmek için kurumsal desteğe bel bağlar.

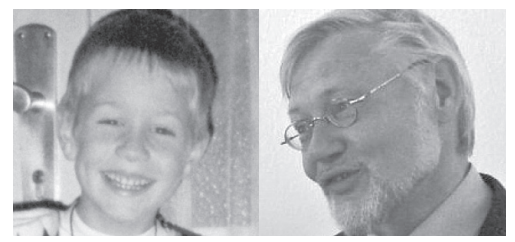

Bernd Trocholepczy 